\section{Kidney \\ Blood Pressure Research}

Kidney Blood Press Res 2015;40:101-110

\begin{tabular}{l|l}
\hline DOI: $10.1159 / 000368486$ & C 2015 S. Karger AG, Base
\end{tabular}

Published online: March 13, 2015

Accepted: February 13, 2015

\title{
Urinary Angiotensin Converting Enzyme 2 Increases in Patients With Type 2 Diabetic Mellitus
}

\author{
Yaoxian Liang, Hui Deng, Shuhong Bi, Zhuan Cui, Lata A, Danxia Zheng, Yue Wang \\ Department of Nephrology, Peking University Third Hospital, Beijing 100191, China
}

\section{Key Words}

Diabetic nephropathy - Angiotensin converting enzyme 2 - Renin angiotensin system • Hypertension

\begin{abstract}
Background/Aims: Angiotensin converting enzyme 2 (ACE2) is highly expressed in the kidney and recognized to be renoprotective by degrading Angiotensin II to Angiotensin (17) in diabetic nephropathy. However, little is known about the role of urinary ACE2 (UACE2) in diabetes. The present study was performed to evaluate UACE2 levels in type 2 diabetic patients with various degrees of albuminuria and its associations with metabolic parameters. The effect of RAS inhibitors on UACE2 excretion was also assessed. Methods: A total of 132 type 2 diabetic patients with different degrees of albuminuria and 34 healthy volunteers were studied. UACE2 levels and activity were measured. Results: Compared to healthy controls, UACE2 to creatinine (UACE2/Cr) levels were significantly increased in both albuminuric and non-albuminuric diabetic patients. UACE2/Cr levels were much higher in hypertensive diabetic patients compared with their normotensive counterparts and treatment with RAS inhibitors markedly attenuated the augmentation. Furthermore, UACE2/Cr was positively correlated with fasting blood glucose, hemoglobin $\mathrm{A} 1 \mathrm{C}(\mathrm{HbA} 1 \mathrm{C})$, triglyceride, and total cholesterol. In multiple regression analysis, UACE2/Cr was independently predicted by $\mathrm{HbA} 1 \mathrm{C}$ and RAS inhibitors treatment. Conclusions: UACE2 increased in type 2 diabetic patients with various degrees of albuminuria and RAS inhibitors suppresses UACE2 excretion. UACE2 might potentially function as a marker for monitoring the metabolic status and therapeutic response of RAS inhibitors in diabetes.
\end{abstract}

Copyright $(2015$ S. Karger AG, Basel

\section{Introduction}

Diabetic nephropathy (DN) is a leading cause of end stage renal disease and associated with increased risk of cardiovascular disease and all-cause mortality [1,2]. Over-activation of the angiotensin converting enzyme (ACE) - angiotensin II (Ang II) - AT1 receptor axis 


\section{Kidney \\ Blood Pressure Research}

Kidney Blood Press Res 2015;40:101-110

\begin{tabular}{l|l}
\hline DOI: $10.1159 / 000368486$ & (C) 2015 S. Karger AG, Basel
\end{tabular}

Published online: March 13, 2015

www.karger.com/kbr

in the intrarenal renin angiotensin system (RAS) is considered to play a pivotal role in the progression of DN. In recent years, ACE2 has been identified to be an important component of the RAS [3, 4]. ACE2 is a membrane-bound metallopeptidase that shares $42 \%$ sequence homology with ACE. Unlike ACE, which cleaves C-terminal dipeptides from Ang I to generate Ang II, ACE2 maintains the balance of the RAS by removing single amino acid from the C-terminus of Ang II to generate Ang (1-7). Moreover, ACE2 could convert Ang I to Ang (1-9), which could be further cleaved by ACE to form Ang (1-7) [3-5]. Ang (1-7) is recognized as a novel renoprotective peptide by mediating vasodilatory, natriuretic and antifibrotic effects through binding to the Mas receptor [6].

In kidneys, ACE2 is known to localize mainly to the apical border of the proximal convoluted tubules [7]. Studies involving STZ diabetic rats, $\mathrm{db} / \mathrm{db}$ diabetic mice and patients with DN demonstrated decreased ACE2 expression in renal tissues [7-9]. Furthermore, high glucose down-regulated ACE2 expression in cultured tubular epithelial cells via the TGF- $\beta$ pathway [10]. On the other hand, ACE2 overexpression or recombinant ACE2 administration ameliorated kidney injury in diabetic animal models [11,12]. Collectively, ACE2 might be highly involved in the pathogenesis of DN and thus a promising diagnostic and therapeutic target of DN.

Recently, soluble ACE2 in urine, which is most likely due to proteolytic shedding of its ectodomain from cells along the nephron, has been detected in several clinical and experimental studies [13-17]. It was reported that urinary ACE2 (UACE2) levels were significantly increased in patients with chronic kidney disease (CKD) and in renal transplant recipients compared with healthy subjects $[13,14]$. In a more recent study, Park and colleagues demonstrated that UACE2 levels were much higher in insulin-resistant subjects with impaired fasting glucose (IFG), impaired glucose tolerance (IGT), and type 2 diabetes mellitus (T2DM) than in the normal glucose tolerance (NGT) group [15]. Moreover, a positive relationship between mRNA expression of ACE2 in urinary cell pellets and the degree of proteinuria was observed in patients with type 2 DN [18]. However, it's worth pointing out that ACE2 mRNA expression in urinary sediment do not reflect the levels of soluble ACE2 cleaved from tubular cells. So the changes of urinary soluble ACE2 excretion in DN patients and its association with the severity and progression of DN are still not fully elucidated.

The aim of this study was therefore to examine UACE2 concentrations in type 2 diabetic patients with different grades of proteinuria. In addition, we also evaluated the associations between UACE2 levels and various metabolic parameters.

\section{Materials and Methods}

\section{Subjects}

The study protocol was approved by the Peking University Biomedical Ethics Committee (Beijing, China). A total of 179 patients hospitalized for T2DM in Peking University Third Hospital between September 2013 and December 2013 were recruited. The exclusion criteria included patients with primary glomerulonephritis, renal artery stenosis, estimated glomerular filtration rate (eGFR) below $30 \mathrm{ml} / \mathrm{min}$, cerebrovascular disease, heart failure, liver dysfunction, malignancy, and pregnant women. Consequently, 132 diabetic patients (54 patients with normotension and 78 with hypertension) and another 34 healthy volunteers were enrolled in the study. Diabetic patients were divided into three groups according to the levels of urinary albumin to creatinine ratio (UALB/Cr): T2DM with normoalbuminuria (UALB/Cr $<30$ $\mathrm{mg} / \mathrm{g}, \mathrm{n}=48)$, T2DM with microalbuminuria $(30 \mathrm{mg} / \mathrm{g}<\mathrm{UALB} / \mathrm{Cr}<300 \mathrm{mg} / \mathrm{g}, \mathrm{n}=41)$, and T2DM with macroalbuminuria (UALB/Cr $>300 \mathrm{mg} / \mathrm{g}, \mathrm{n}=43$ ) [19].

\section{Clinical data}

Seated blood pressures were measured using a sphygmomanometer after at least 5 min of rest in two different days and the results were averaged. Clinical parameters were measured by standard methods in our clinical laboratory. UACE2 and urinary albumin (UALB) were detected on the same urine specimens and adjusted with same sample creatinine and expressed as UACE2/Cr or UALB/Cr. eGFR was calculated using 


\section{Kidney \\ Blood Pressure Research}

Kidney Blood Press Res 2015;40:101-110

\begin{tabular}{l|l}
\hline DOI: $10.1159 / 000368486$ & (C) 2015 S. Karger AG, Basel
\end{tabular}

Published online: March 13, 2015

www.karger.com/kbr

the Modification of Diet in Renal Disease (MDRD) Formula: eGFR $=175 \times[\text { serum creatinine }(\mathrm{mg} / \mathrm{dl})]^{-1.154} \times$ $\operatorname{age}^{-0.203}(\times 0.742$ if female $)$.

Sample collections and urinary ACE2 measurement by ELISA

Morning spot urine samples were obtained when the participants were free of fever or infections. Urine specimens (without protease inhibitor) were immediately centrifuged at $3000 \mathrm{rpm}$ for $10 \mathrm{~min}$ at $4^{\circ} \mathrm{C}$ and aliquoted to store at $-80^{\circ} \mathrm{C}$ until use. Urinary concentrations of ACE2 were measured with human ACE2 enzyme-linked immunosorbent assay (ELISA) kits (Cat. \# AG-45A-0022EK-KI01, AdipoGen, Seoul, Korea) following the manufacturer's instructions. Briefly, $100 \mu \mathrm{l}$ of urine sample (1:2 dilution with ELISA buffer) was added to each well of the plates and incubated at $37^{\circ} \mathrm{C}$ for $1 \mathrm{~h}$. Then the plates were washed three times and incubated with detection antibody against human ACE2 at $37^{\circ} \mathrm{C}$ for $1 \mathrm{~h}$. After washing, a colorimetric reaction was performed using horseradish peroxidase labeled streptavidin at $37^{\circ} \mathrm{C}$ for $1 \mathrm{~h}$. Then $100 \mu \mathrm{l}$ of TMB solution was added to each well and incubated in dark at room temperature for $30 \mathrm{~min}$. Finally, the reaction was stopped with sulfuric acid and the absorbance values were measured at $450 \mathrm{~nm}$ with a Model 680 microplate reader (Bio-Rad, Hercules, CA, USA). The assay was repeated twice and the values were averaged.

Detection of urinary ACE2 activity

Urinary ACE2 activity was measured using a fluorescent substrate-based assay as previously described [20]. Briefly, urine aliquots $(20 \mu \mathrm{l})$ were incubated on 96-well plates with the reaction buffer ( $50 \mathrm{mM}$ MES, $300 \mathrm{mM} \mathrm{NaCl}, 10 \mu \mathrm{M} \mathrm{ZnCl}_{2}, 1 \mathrm{mM} \mathrm{N}$-ethylmaleimide, $1 \mathrm{mM}$ phenylmethylsulfonyl fluoride) and $50 \mu \mathrm{M}$ of the ACE2 substrate Mca-Ala-Pro-Lys(Dnp)-OH (Enzo Life Sciences, NY, USA), with or without $1 \mu \mathrm{M}$ of the ACE2 inhibitor DX600 (Phoenix Pharmaceuticals, CA, USA). The total volume for each well was $100 \mu \mathrm{l}$. After incubation at room temperature for $2 \mathrm{hrs}$, fluorescence was measured using a Modulus ${ }^{\mathrm{TM}}$ single-tube multimode reader (Turner Biosystems, CA, USA) with an excitation wavelength of $320 \mathrm{~nm}$ and an emission wavelength of $405 \mathrm{~nm}$. ACE2 activity was determined by subtracting the absorbance value in the presence of DX600 from those in its absence. Results were corrected for the urinary creatinine concentration and presented as RFU / $\mu \mathrm{g} \mathrm{Cr} / \mathrm{hr}$.

\section{Western blot analysis for urinary ACE2}

Urine samples each containing $10 \mu \mathrm{g}$ of creatinine were separated on $10 \%$ sodium dodecyl-sulfate polyacrylamide gel. After electroblotted to a nitrocellulose membrane and blocking for 1 hour, the proteins were incubated overnight at $4^{\circ} \mathrm{C}$ with rabbit anti-ACE2 (1:1000, Cat. \# ab108252, Abcam, Cambridge, UK) followed by incubation with HRP-conjugated donkey anti-rabbit (1:2000, Jackson Immuno-Research, USA) secondary antibody. Signals were visualized using the SuperSignal West Pico chemiluminescence kit (Perbio, Cramlington, Northumberland, UK).

\section{Statistical analysis}

Data are presented as the means \pm standard deviation and analyzed using SPSS 16.0 for Windows. One-way analysis of variance (ANOVA) was used for comparisons of continuous variables and $\chi^{2}$ tests for comparison of categorical variables. Pearson correlation analyses were performed to identify the associations of UACE2/Cr and clinical parameters. Backward multiple regression analyses were adopted to calculate the influence of the potential risk predictors on the UACE2/Cr levels. P values $<0.05$ were considered statistically significant.

\section{Results}

Subjects profiles and laboratory data

The demographics and laboratory data of all participants are illustrated in Table 1.

UACE2 levels in diabetic patients and healthy volunteers

Figure 1 exhibits UACE2/Cr levels in patients with T2DM and healthy controls. UACE2/Cr 


\section{Kidney \\ Blood Pressure Research}

Table 1. Characteristics of 132 diabetic patients and 34 healthy controls

\begin{tabular}{|c|c|c|c|c|}
\hline \multirow[b]{2}{*}{ Variables } & \multirow{2}{*}{$\begin{array}{l}\text { Control group } \\
\quad(\mathrm{n}=34)\end{array}$} & \multicolumn{3}{|c|}{ Patients with T2DM $(\mathrm{n}=132)$} \\
\hline & & $\begin{array}{l}\text { Normoalbuminuria } \\
\text { group }(n=48)\end{array}$ & $\begin{array}{l}\text { Microalbuminuria } \\
\text { group }(\mathrm{n}=41)\end{array}$ & $\begin{array}{l}\text { Macroalbuminuria } \\
\text { group }(n=43)\end{array}$ \\
\hline Age (years) & $61.31 \pm 8.10$ & $61.82 \pm 13.34$ & $65.35 \pm 13.32$ & $56.77 \pm 15.38$ \\
\hline Male/Female (n) & $16 / 18$ & $25 / 23$ & $24 / 17$ & $23 / 20$ \\
\hline BMI $\left(\mathrm{kg} / \mathrm{m}^{2}\right)$ & $24.77 \pm 2.81$ & $25.25 \pm 3.96$ & $26.79 \pm 2.61$ & $27.04 \pm 3.23^{*}$ \\
\hline SBP (mmHg) & $123.00 \pm 12.14$ & $127.49 \pm 12.35$ & $132.79 \pm 9.73$ & $132.36 \pm 13.16$ \\
\hline DBP (mmHg) & $77.00 \pm 6.72$ & $74.73 \pm 6.83$ & $82.57 \pm 9.46^{\#}$ & $78.80 \pm 11.03$ \\
\hline $\mathrm{FBG}(\mathrm{mmol} / \mathrm{L})$ & $5.50 \pm 0.37$ & $8.41 \pm 3.29^{*}$ & $8.02 \pm 2.684^{*}$ & $8.11 \pm 2.49^{*}$ \\
\hline $\operatorname{HbA1C}(\%)$ & $5.11 \pm 0.25$ & $8.63 \pm 1.58^{*}$ & $8.02 \pm 2.02^{*}$ & $7.31 \pm 1.98^{* \#}$ \\
\hline $\mathrm{TG}(\mathrm{mmol} / \mathrm{L})$ & $1.68 \pm 0.95$ & $2.22 \pm 2.29$ & $1.76 \pm 1.18$ & $2.71 \pm 2.53$ \\
\hline $\mathrm{TC}(\mathrm{mmol} / \mathrm{L})$ & $4.10 \pm 0.43$ & $4.49 \pm 1.24$ & $4.36 \pm 1.13$ & $4.60 \pm 1.08$ \\
\hline Serum ALB $(g / L)$ & $43.96 \pm 1.49$ & $41.05 \pm 2.33^{*}$ & $42.34 \pm 3.47$ & $39.11 \pm 6.27^{*}$ \\
\hline $\operatorname{Scr}(\mu \mathrm{mol} / \mathrm{L})$ & $74.11 \pm 12.11$ & $75.40 \pm 12.63$ & $93.21 \pm 19.95^{* \#}$ & $129.83 \pm 56.43^{*} \# \Delta$ \\
\hline $\mathrm{UA}(\mu \mathrm{mol} / \mathrm{L})$ & $283.95 \pm 61.69$ & $327.72 \pm 76.93^{*}$ & $318.30 \pm 65.36$ & $378.09 \pm 87.33^{*} \# \Delta$ \\
\hline $\mathrm{UALB} / \mathrm{Cr}(\mathrm{mg} / \mathrm{g})$ & $6.64 \pm 2.70$ & $11.73 \pm 5.04$ & $181.60 \pm 59.37^{* \#}$ & $\begin{array}{c}6316.05 \pm \\
3067.26^{* \# \Delta}\end{array}$ \\
\hline eGFR (ml/min/1.73m²) & $91.15 \pm 15.89$ & $94.97 \pm 16.27$ & $76.55 \pm 21.67 \#$ & $60.83 \pm 26.93^{* \#}$ \\
\hline Duration of diabetes (month) & 0 & $130.2^{*}$ & $136.9^{*}$ & $151.6^{*}$ \\
\hline Insulin treatment (n) & 0 & $27^{*}$ & $23^{*}$ & $30^{*}$ \\
\hline Oral antidiabetic treatment (n) & 0 & $35^{*}$ & $30 *$ & $21^{*}$ \\
\hline RAS inhibitors treatment (n) & 0 & $16^{*}$ & $24^{*}$ & $18^{*}$ \\
\hline \multicolumn{5}{|c|}{$\begin{array}{l}{ }^{*} \mathrm{P}<0.05 \text { vs. Control group, }{ }^{*} \mathrm{P}<0.05 \text { vs. normoalbuminuria group, } \triangle \mathrm{P}<0.05 \text { vs. microalbuminuria group. BMI, body } \\
\text { mass index; SBP, systolic blood pressure; DBP, diastolic blood pressure; FBG, fasting blood glucose; HbA1C, hemoglobin } \\
\text { A1C; TG, triglyceride; TC, total cholesterol; ALB, albumin; Scr, serum creatinine; UA, uric acid; UALB/Cr, urinary albumin } \\
\text { to creatinine ratio; eGFR, estimated glomerular filtration rate; RAS, renin angiotensin system }\end{array}$} \\
\hline
\end{tabular}

levels were significantly higher in diabetic patients with normoalbuminuria compared with healthy subjects $(33.64 \pm 20.97$ $\mu \mathrm{g} / \mathrm{g}$ vs. $6.29 \pm 5.18 \mu \mathrm{g} / \mathrm{g}, \mathrm{P}<0.001$ ), indicating that UACE2 increases early in the premicroalbuminuric phase of diabetes. However, no significant change was observed in UACE2/Cr levels among T2DM patients with different degrees of albuminuria.

\section{ACE2 enzyme activity in urine}

Consistent with UACE2 levels measured by ELISA, we found increased ACE2 enzyme activity in urine from both albuminuric and non-albuminuric diabetic patients as compared to healthy controls. Again, there was no difference in urinary ACE2 activity among diabetic patients with different degrees of albuminuria (Figure 2).

Western blot analysis for urinary ACE2

A doublet of $\sim 120 \mathrm{kDa}$ and $\sim 70 \mathrm{kDa}$ bands were observed in the urine of diabetic patients, whereas a single $\sim 120 \mathrm{kDa}$ band was visible in the control group (Figure $3 \mathrm{~A}$ ).

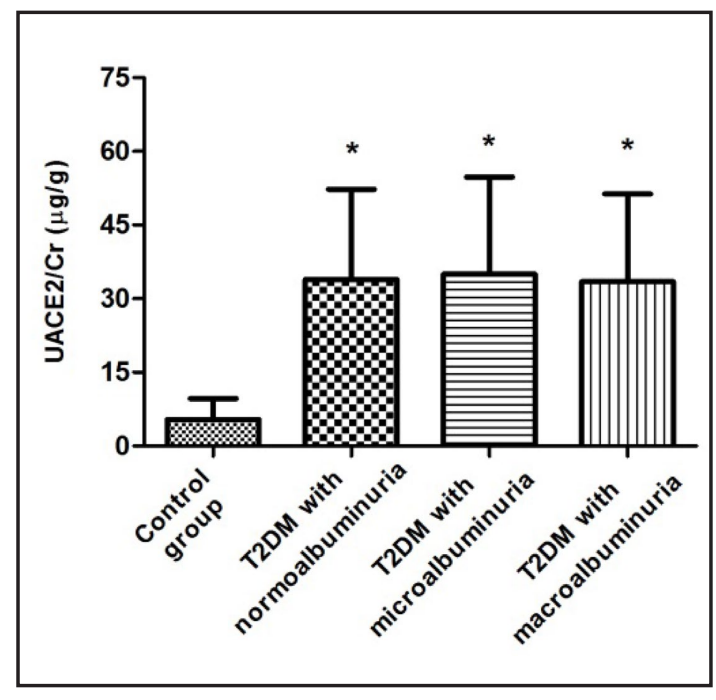

Fig. 1. UACE2/Cr levels in diabetic patients and healthy controls. UACE2/Cr levels were significantly higher in diabetic patients compared to healthy controls but comparable among patients with different degrees of albuminuria. ${ }^{*} \mathrm{P}<0.001$ vs. Control group.

The relative abundance of the ACE2 protein band at both $\sim 120 \mathrm{kDa}$ and $\sim 70 \mathrm{kDa}$ were remarkably increased in urine from diabetic patients as compared to urine from healthy controls (Figure 3B). 


\section{Kidney \\ Blood Pressure \\ Research}

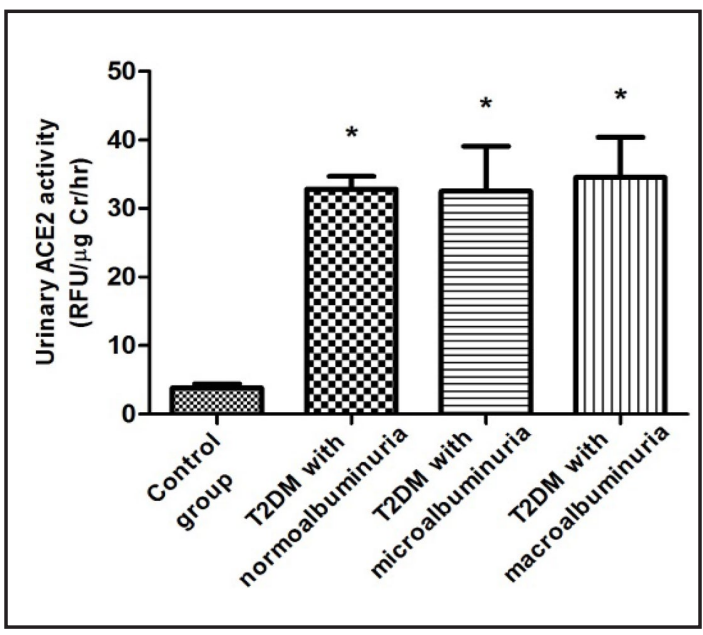

Fig. 2. ACE2 enzyme activity in urine. Urinary ACE2 activity in diabetic patients was markedly higher than that in the control group. No significant change was observed in urinary ACE2 activity among diabetic patients with different degrees of albuminuria. $* \mathrm{P}<0.001$ vs. Control group.

UACE2 levels in hypertensive T2DM patients with/without RAS blockade

To further identify the effect of hypertension and RAS blockade on UACE2 excretion, T2DM patients were divided into three subgroups: normotensive patients (T2DM+ non-HTN, n=54), hypertensive patients treated with antihypertensive drugs other than RAS inhibitors (T2DM+ HTN+ non-RASI, $\mathrm{n}=20$ ), and hypertensive patients with RAS inhibitors (T2DM+ HTN+RASI, $\mathrm{n}=58$ ). Table 2 showed the characteristics of hypertensive patients with RAS inhibitors and other antihypertensive drugs. UACE2/Cr levels were significantly enhanced in normotensive T2DM patients compared with healthy subjects $(38.29 \pm 17.47 \mu \mathrm{g} / \mathrm{g}$ vs. $6.29 \pm$ $5.18 \mu \mathrm{g} / \mathrm{g}, \mathrm{P}<0.001$ ) and displayed a further increase in hypertensive T2DM patients without RAS blockade $(52.92 \pm 24.02 \mu \mathrm{g} / \mathrm{g}$ vs. $38.29 \pm 17.47 \mu \mathrm{g} / \mathrm{g}, \mathrm{P}=0.048)$. Importantly, treatment with RAS inhibitors markedly ameliorated the elevation of UACE2 excretion (32.35 \pm 20.77 $\mu \mathrm{g} / \mathrm{g}$ vs. $52.92 \pm 24.02 \mu \mathrm{g} / \mathrm{g}, \mathrm{P}=0.001$ ) (Figure 4).

\section{Single regression analyses}

Figure 5 demonstrates single regression analyses for UACE2/Cr with clinical parameters. In patients with T2DM, UACE2/Cr levels were not correlated with age, gender, body mass index (BMI), systolic blood pressure (SBP), diastolic blood pressure (DBP), serum albumin (ALB), serum creatinine (Scr), uric acid (UA), $\log (\mathrm{UALB} / \mathrm{Cr}$ ) levels or eGFR. However UACE2/Cr levels were significantly correlated positively with fasting blood glucose (FBG), hemoglobin A1C (HbA1C), total cholesterol (TC) and triglyceride (TG). 


\section{Kidney \\ Blood Pressure Research}

Table 2. Comparison of hypertensive diabetic patients with and without RAS inhibitors
Kidney Blood Press Res 2015;40:101-110

\begin{tabular}{l|l}
\hline DOI: $10.1159 / 000368486$ & C 2015 S. Karger AG, Basel
\end{tabular}

Published online: March 13, 2015

www.karger.com/kbr

Liang/Deng/Bi/Cui/A/Zheng/Wang: Urinary ACE2 Increases in Diabetic Patients

\begin{tabular}{lccc}
\hline Variables & RAS inhibitors & $\begin{array}{c}\text { Other antihyper- } \\
\text { tensive drugs }\end{array}$ & P value \\
\hline No. of patients (n) & 58 & 20 & - \\
Male/Female (n) & $32 / 26$ & $12 / 8$ & 0.267 \\
SBP (mmHg) & $134.34 \pm 11.20$ & $141.04 \pm 15.50$ & 0.142 \\
DBP (mmHg) & $79.14 \pm 10.38$ & $78.63 \pm 10.64$ & 0.889 \\
\hline RAS, renin angiotensin system; SBP, systolic blood pressure; DBP, \\
diastolic blood pressure
\end{tabular}

Fig. 4. UACE2 levels in normotensive and hypertensive T2DM patients with/without RAS blockade. UACE2/Cr levels were significantly enhanced in hypertensive T2DM patients compared with normotensive T2DM patients and RAS inhibitors markedly suppressed the elevation. ${ }^{*} \mathrm{P}<0.001$ vs. Control group, \# $\mathrm{P}<0.05$ vs. T2DM + non-HTN group, $\Delta \mathrm{P}<$ 0.01 vs. T2DM + HTN + non-RASI group.

Fig. 5. Single regression analyses for UACE2/Cr. UACE2/Cr levels were significantly correlated positively with FBG (A, r = 0.245, P = 0.027), $\operatorname{HbA1C}(\mathrm{B}, \mathrm{r}$ $=0.272, \mathrm{P}=0.014), \mathrm{TC}(\mathrm{C}, \mathrm{r}=0.334, \mathrm{P}=0.004)$ and TG (D, $r=0.340, P=0.005)$.

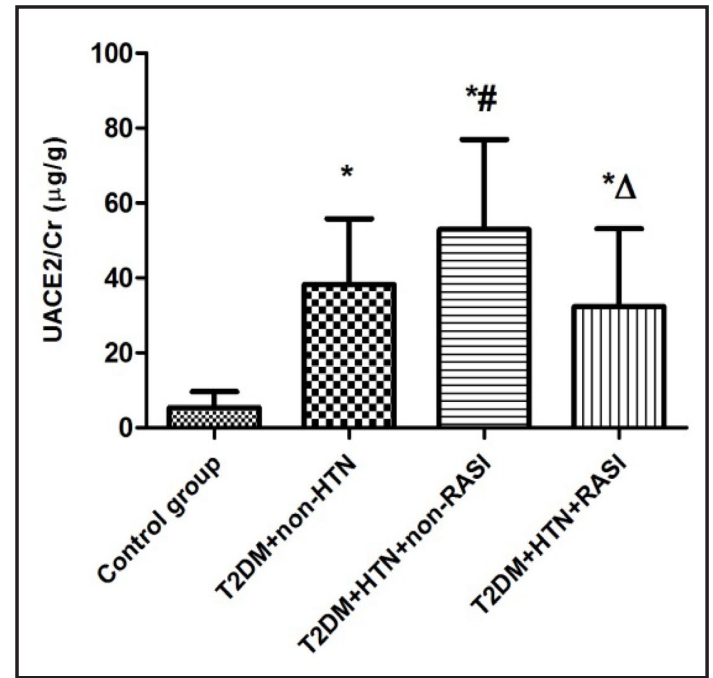

$\nabla$

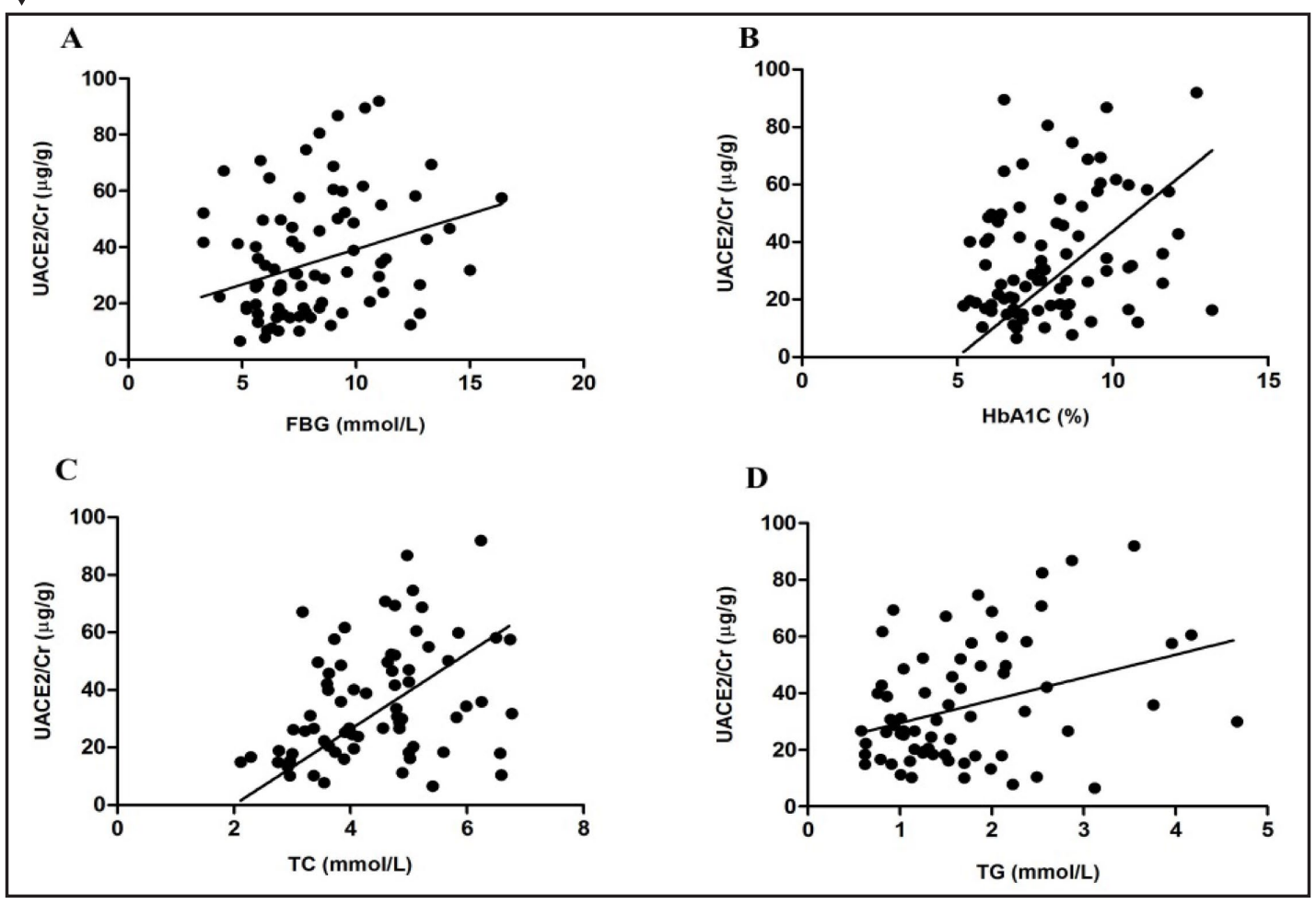

Multiple regression analyses

Factors with significant single correlation with UACE2/Cr levels were adopted as explanatory variables in multiple regression analyses. The original model included FBG, HbA1C, 


\section{Kidney Blood Pressure Research}

Kidney Blood Press Res 2015;40:101-110

DOI: 10.1159/000368486

Published online: March 13, 2015

(c) 2015 S. Karger AG, Basel

Liang/Deng/Bi/Cui/A/Zheng/Wang: Urinary ACE2 Increases in Diabetic Patients

TC, TG, hypertension and use of RAS inhibitors. As a result, FBG, TC, TG and hypertension were excluded. UACE2/ $\mathrm{Cr}$ was independently predicted by HbA1C levels and the use of RAS inhibitors in diabetic patients (Table 3).
Table 3. Multiple regression analyses for UACE $2 / \mathrm{Cr}$

\begin{tabular}{lcccc}
\hline & \multicolumn{4}{c}{ UACE2/Cr $(\mu \mathrm{g} / \mathrm{g})$} \\
\cline { 2 - 5 } & $\mathrm{B}$ & $\mathrm{SE}$ & $\mathrm{t}$ & P value \\
\hline Constant & 8.819 & 13.313 & 0.662 & 0.511 \\
HbA1C $(\%)$ & 4.056 & 1.428 & 2.840 & 0.006 \\
Use of RAS Inhibitors & -10.325 & 5.155 & -2.003 & 0.050 \\
\hline
\end{tabular}

HbA1C, hemoglobin A1C; RAS, renin angiotensin system

\section{Discussion}

Three major findings were noted in this study. First, UACE2/Cr levels increased significantly in T2DM patients compared with healthy controls. However, no difference of UACE2/ Cr levels was observed in albuminuric T2DM patients compared with their normoalbuminuric counterparts. Secondly, UACE2/Cr levels were much greater in hypertensive T2DM patients than both normotensive T2DM patients and healthy subjects. In particular, RAS blockade could prevent the augmentation of UACE2. Thirdly, UACE2/Cr levels were significantly correlated with FBG, HbA1C, TC, and TG, and independently predicted by HbA1C levels and RAS inhibitors treatment in diabetic patients.

ACE2 is abundantly expressed in the kidney, predominantly localized to the apical surface of proximal tubular cells where it is proteolytically cleaved within its ectodomain to release a soluble form in the urine $[7,21]$. The degradation fragment of ACE2 was found to be about $70 \mathrm{kDa}$ and the glycosylated form $120 \mathrm{kDa}[4,13,16,22]$. A majority of studies, except the one from Ye $\mathrm{M}$, have confirmed that tubular ACE2 decreased significantly in diabetic patients and animal models [7-9]. On the other hand, UACE2 excretion significantly increased in uncomplicated type 1 diabetic patients, insulin-resistant subjects, CKD patients and renal transplant recipients, indicating it might be a potential marker for diabetes and kidney disease [13-15, 23]. Consistent with these studies, we showed that UACE2/Cr levels were much higher in type 2 DN patients. Importantly, UACE2/Cr levels increased remarkably even in diabetic patients without albuminuria, suggesting that augmented UACE2 excretion is likely to precede the onset of albuminuria in type 2 diabetic patients. Nevertheless, due to the cross-sectional design of the study, one cannot exclude the possibility that albuminuria has once appeared and presently regressed in the non-albuminuric patients. In addition, it should be noted that it is a limitation that protease inhibitor was not added to the urine samples when ACE2 was detected.

It has been previously reported that a disintegrin and metalloproteinase 17 (ADAM17), a transmembrane glycoprotein involved in proteolytical cleavage of numerous cell-surface proteins, is responsible for the enhanced ectodomain shedding of ACE2 in vitro [2426]. More recently, several investigations revealed significant increase in renal ADAM17 expression and UACE2 excretion in diabetic mice, which were reversed by chronic treatment with insulin or the insulin sensitizer rosiglitazone [17, 27, 28]. Also, high glucose increased ADAM17 activity and ACE2 shedding in cultured mouse proximal tubular cells [22]. In the present study, UACE2/Cr levels were significantly correlated positively with FBG and HbA1C. Multiple regression analysis showed that UACE2/Cr appears to be independently predicted by $\mathrm{HbA} 1 \mathrm{C}$ levels. Moreover, both approximately $120 \mathrm{kDa}$ and $70 \mathrm{kDa}$ of ACE2 were observed in the urine from diabetic patients, indicating increased degradation and glycosylation of ACE2. Taken together, it is plausible to speculate that hyperglycemia might up-regulate renal ADAM17 expression and thus leads to increased ACE2 shedding from tubular epithelial cells in type 2 DM patients. The exact mechanisms underlying ACE2 shedding in different stages of diabetes need to be further elucidated. 


\section{Kidney \\ Blood Pressure Research}

A particular concern is whether ACE2 could be filtered through the glomerular basement membrane in DN patients with disrupted filtration barrier. In diabetic mice with albuminuria, soluble recombinant ACE2 infusion failed to increase UACE2 levels [16]. Indeed, plasma ACE2 is undetectable in healthy individuals due to the presence of an endogenous inhibitor or little constitutive shedding from the plasma membrane $[29,30]$. In a recent study, Chodavarapu et al. confirmed the absence of circulatory ACE2 in experimental diabetic mice [17]. Furthermore, the high molecular weight of soluble ACE2 $(120 \mathrm{kDa})$ indicates that little could filtrate across the glomerular barrier. Consistent with these results, our findings showed that UACE2/Cr levels were comparable among patients with different grades of proteinuria and there was no association between UACE2/Cr and $\log (\mathrm{UALB} / \mathrm{Cr}$ ) levels. Altogether, these data indicate that, in patients with type 2 DN, UACE2 is more likely of tubular origin instead of filtrating from circulation.

Another important finding of our study was that UACE2/Cr levels were much higher in hypertensive T2DM patients compared to their normotensive counterparts. On the other hand, treatment with RAS blockers significantly attenuated the augmentation of UACE2/Cr levels in hypertensive diabetic patients. Based on these results we suggest that, in addition to their antihypertensive effects, RAS inhibitors might be useful in preventing tubular ACE2 shedding by blocking intrarenal Ang II in patients with DN. Our hypothesis is also supported by another study that pharmacologic inhibition of AT1 receptor considerably attenuated Ang II induced renal ADAM17 overexpression in subtotally nephrectomized mice [31]. These data highlight the potential role of UACE2 as a marker for assessing the therapeutic response of renoprotective antihypertensive drugs. However, it should be noted that published data on this area are conflicting. Reports by Mizuiri et al. and Wysocki et al. showed no change in UACE2 excretion after RAS inhibitors administration in CKD patients and $d b / d b$ diabetic mice $[13,16]$. We interpret with caution that different disease states and periods might be responsible for the discrepancy. Prospective studies are needed to provide additional information on this issue.

\section{Conclusion}

In summary, the present study demonstrates that increased UACE2 levels are significantly correlated with FBG, HbA1C, TG, TC and RAS blockade could attenuate the augmentation, suggesting UACE2 to be a noninvasive indicator for the metabolic status and therapeutic response of RAS inhibitors in DN patients. Given the renoprotective effects of ACE2, pharmacologic inhibition of its shedding from renal tubular cells might be a potential therapeutic target for DN.

\section{Disclosure Statement}

The authors of this manuscript state that they do not have any conflict of interests and nothing to disclose.

\section{Acknowledgements}

This work was supported by the National Natural Science Foundation of China (81070213). The funders had no role in study design, data collection and analysis, decision to publish, or preparation of the manuscript. 


\section{Kidney \\ Blood Pressure Research}

Kidney Blood Press Res 2015;40:101-110

\begin{tabular}{l|l}
\hline DOI: $10.1159 / 000368486$ & (C) 2015 S. Karger AG, Basel
\end{tabular}

Published online: March 13, 2015

www.karger.com/kbr

Liang/Deng/Bi/Cui/A/Zheng/Wang: Urinary ACE2 Increases in Diabetic Patients

\section{References}

1 The effect of intensive treatment of diabetes on the development and progression of long-term complications in insulin-dependent diabetes mellitus. The Diabetes Control and Complications Trial Research Group. N Engl J Med 1993;329:977-986.

2 Coresh J, Selvin E, Stevens LA, Manzi J, Kusek JW, Eggers P, Van Lente F, Levey AS: Prevalence of chronic kidney disease in the United States. JAMA 2007;298:2038-2047.

3 Donoghue M, Hsieh F, Baronas E, Godbout K, Gosselin M, Stagliano N, Donovan M, Woolf B, Robison K, Jeyaseelan R, Breitbart RE, Acton S: A novel angiotensin-converting enzyme-related carboxypeptidase (ACE2) converts angiotensin I to angiotensin 1-9. Circ Res 2000;87:E1-9.

4 Tipnis SR, Hooper NM, Hyde R, Karran E, Christie G, Turner AJ: A human homolog of angiotensinconverting enzyme. Cloning and functional expression as a captopril-insensitive carboxypeptidase. J Biol Chem 2000;275:33238-33243.

5 Ferrario CM, Varagic J: The ANG-(1-7)/ACE2/mas axis in the regulation of nephron function. Am J Physiol Renal Physiol 2010;298:F1297-1305.

6 Simoes e Silva AC, Silveira KD, Ferreira AJ, Teixeira MM: ACE2, angiotensin-(1-7) and Mas receptor axis in inflammation and fibrosis. Br J Pharmacol 2013;169:477-492.

7 Ye M, Wysocki J, William J, Soler MJ, Cokic I, Batlle D: Glomerular localization and expression of Angiotensin-converting enzyme 2 and Angiotensin-converting enzyme: implications for albuminuria in diabetes. J Am Soc Nephrol 2006;17:3067-3075.

8 Tikellis C, Johnston CI, Forbes JM, Burns WC, Burrell LM, Risvanis J, Cooper ME: Characterization of renal angiotensin-converting enzyme 2 in diabetic nephropathy. Hypertension 2003;41:392-397.

9 Reich HN, Oudit GY, Penninger JM, Scholey JW, Herzenberg AM: Decreased glomerular and tubular expression of ACE2 in patients with type 2 diabetes and kidney disease. Kidney Int 2008;74:1610-1616.

10 Chou CH, Chuang LY, Lu CY, Guh JY: Interaction between TGF-beta and ACE2-Ang-(1-7)-Mas pathway in high glucose-cultured NRK-52E cells. Mol Cell Endocrinol 2013;366:21-30.

11 Nadarajah R, Milagres R, Dilauro M, Gutsol A, Xiao F, Zimpelmann J, Kennedy C, Wysocki J, Batlle D, Burns KD: Podocyte-specific overexpression of human angiotensin-converting enzyme 2 attenuates diabetic nephropathy in mice. Kidney Int 2012;82:292-303.

12 Oudit GY, Liu GC, Zhong J, Basu R, Chow FL, Zhou J, Loibner H, Janzek E, Schuster M, Penninger JM, Herzenberg AM, Kassiri Z, Scholey JW: Human recombinant ACE2 reduces the progression of diabetic nephropathy. Diabetes 2010;59:529-538.

13 Mizuiri S, Aoki T, Hemmi H, Arita M, Sakai K, Aikawa A: Urinary angiotensin-converting enzyme 2 in patients with CKD. Nephrology (Carlton) 2011;16:567-572.

14 Xiao F, Hiremath S, Knoll G, Zimpelmann J, Srivaratharajah K, Jadhav D, Fergusson D, Kennedy CR, Burns KD: Increased urinary angiotensin-converting enzyme 2 in renal transplant patients with diabetes. PLoS One 2012;7:e37649.

15 Park SE, Kim WJ, Park SW, Park JW, Lee N, Park CY, Youn BS: High urinary ACE2 concentrations are associated with severity of glucose intolerance and microalbuminuria. Eur J Endocrinol 2013;168:203-210.

16 Wysocki J, Garcia-Halpin L, Ye M, Maier C, Sowers K, Burns KD, Batlle D: Regulation of urinary ACE2 in diabetic mice. Am J Physiol Renal Physiol 2013;305:F600-611.

17 Chodavarapu H, Grobe N, Somineni HK, Salem ES, Madhu M, Elased KM: Rosiglitazone treatment of type 2 diabetic $\mathrm{db} / \mathrm{db}$ mice attenuates urinary albumin and angiotensin converting enzyme 2 excretion. PLoS One 2013;8:e62833.

18 Wang G, Lai FM, Lai KB, Chow KM, Kwan CH, Li KT, Szeto CC: Urinary mRNA expression of ACE and ACE2 in human type 2 diabetic nephropathy. Diabetologia 2008;51:1062-1067.

19 Kdoqi: KDOQI Clinical Practice Guidelines and Clinical Practice Recommendations for Diabetes and Chronic Kidney Disease. Am J Kidney Dis 2007;49:S12-154.

20 Vickers C, Hales P, Kaushik V, Dick L, Gavin J, Tang J, Godbout K, Parsons T, Baronas E, Hsieh F, Acton S, Patane M, Nichols A, Tummino P: Hydrolysis of biological peptides by human angiotensin-converting enzyme-related carboxypeptidase. J Biol Chem 2002;277:14838-14843. 


\section{Kidney \\ Blood Pressure Research}

\section{Kidney Blood Press Res 2015;40:101-110}

DOI: $10.1159 / 000368486$

(C) 2015 S. Karger AG, Basel

www.karger.com/kbr

21 Warner FJ, Lew RA, Smith AI, Lambert DW, Hooper NM, Turner AJ: Angiotensin-converting enzyme 2 (ACE2), but not ACE, is preferentially localized to the apical surface of polarized kidney cells. J Biol Chem 2005;280:39353-39362.

22 Xiao F, Zimpelmann J, Agaybi S, Gurley SB, Puente L, Burns KD: Characterization of angiotensin-converting enzyme 2 ectodomain shedding from mouse proximal tubular cells. PLoS One 2014;9:e85958.

23 Cherney DZ, Xiao F, Zimpelmann J, Har RL, Lai V, Scholey JW, Reich HN, Burns KD: Urinary ACE2 in healthy adults and patients with uncomplicated type 1 diabetes. Can J Physiol Pharmacol 2014;92:703-706.

24 Lambert DW, Yarski M, Warner FJ, Thornhill P, Parkin ET, Smith AI, Hooper NM, Turner AJ: Tumor necrosis factor-alpha convertase (ADAM17) mediates regulated ectodomain shedding of the severe-acute respiratory syndrome-coronavirus (SARS-CoV) receptor, angiotensin-converting enzyme-2 (ACE2). J Biol Chem 2005;280:30113-30119.

25 Iwata M, Silva Enciso JE, Greenberg BH: Selective and specific regulation of ectodomain shedding of angiotensin-converting enzyme 2 by tumor necrosis factor alpha-converting enzyme. Am J Physiol Cell Physiol 2009;297:C1318-1329.

26 Jia HP, Look DC, Tan P, Shi L, Hickey M, Gakhar L, Chappell MC, Wohlford-Lenane C, McCray PB, Jr: Ectodomain shedding of angiotensin converting enzyme 2 in human airway epithelia. Am J Physiol Lung Cell Mol Physiol 2009;297:L84-96.

27 Salem ES, Grobe N, Elased KM: Insulin treatment attenuates renal ADAM17 and ACE2 shedding in diabetic Akita mice. Am J Physiol Renal Physiol 2014;306:F629-639.

28 Riera M, Marquez E, Clotet S, Gimeno J, Roca-Ho H, Lloreta J, Juanpere N, Batlle D, Pascual J, Soler MJ: Effect of insulin on ACE2 activity and kidney function in the non-obese diabetic mouse. PLoS One 2014;9:e84683.

29 Lew RA, Warner FJ, Hanchapola I, Yarski MA, Manohar J, Burrell LM, Smith AI: Angiotensin-converting enzyme 2 catalytic activity in human plasma is masked by an endogenous inhibitor. Exp Physiol 2008;93:685-693.

30 Rice GI, Jones AL, Grant PJ, Carter AM, Turner AJ, Hooper NM: Circulating activities of angiotensinconverting enzyme, its homolog, angiotensin-converting enzyme 2, and neprilysin in a family study. Hypertension 2006;48:914-920.

31 Lautrette A, Li S, Alili R, Sunnarborg SW, Burtin M, Lee DC, Friedlander G, Terzi F: Angiotensin II and EGF receptor cross-talk in chronic kidney diseases: a new therapeutic approach. Nat Med 2005;11:867-874. 